\title{
AKTYWIZACJA I INTEGRACJA MIESZKAŃCÓW GMINY KONOPNICA W ODNIESIENIU DO MOCNYCH I SŁABYCH STRON (ANALIZA SWOT)
}

Zarys treści: Artykuł dotyczy aktywizacji i integracji mieszkańców podmiejskiej gminy Konopnica położonej we wschodniej Polsce. Jednym z elementów funkcjonowania sfery społecznej jest sieć organizacji pozarządowych i różnorodnych form współpracy ze środowiskiem NGO, których rozwój przyczynia się do aktywizacji mieszkańców gminy. Działania skupione są na zachęcaniu miejscowej ludności do angażowania się w prace zespołów sportowych, grup artystycznych, kulinarnych oraz kulturalno-edukacyjnych. Środki na działania aktywizujące pozyskiwane są z Programu Rozwoju Obszarów Wiejskich (PROW na lata 2014-2020).

Słowa kluczowe: Konopnica, województwo lubelskie, aktywizacja, integracja.

\section{Wprowadzenie}

\subsection{Aktywizacja społeczności wiejskiej}

W Polsce, podobnie jak w całej Europie, wsie przekształcają się w osiedla wielofunkcyjne, w których tylko niewielki procent mieszkańców utrzymuje się z rolnictwa. Rdzenni mieszkańcy zasilani są przez dotychczasowych mieszkańców miast, którzy poszukują lokalizacji zapewniającej spokojny tryb życia, jak również pogłębienia życia społecznego (Heffner, Klemens 2012). Świadomi mieszkańcy obszarów wiejskich potrzebują zmian, rozwoju i poprawy warunków życia. K. Heffner i B. Klemens (2012) zwracają uwagę na aktywności, postawy przedsiębiorcze i inicjatywy przekładające się na przekształcanie wsi przy wykorzystaniu procesu budowy więzi społecznych, gospodarczych i kulturowych. Do czynników mających znamiona uwarunkowań rozwoju Z. Brodziński (2011) zalicza: cechy społeczno-kulturowe społeczności lokalnej, zasoby środowiska przyrodniczego, poziom infrastruktury i korzyści związane z położeniem. 
D. Rosiński i A. Rosińska (2011) stwierdzają, że „[...] W dobie dużej dynamiki przemian społeczno-gospodarczych szczególne zainteresowanie wzbudzają zasoby i umiejętności sprzyjające adaptacji oraz aktywnemu włączaniu się mieszkańców w przekształcanie środowiska. Te zasoby są tworzone, testowane, eksploatowane i wzmacniane w różnego typu relacjach. Zasoby kształtują relacje, a równocześnie dzięki tym relacjom możliwe jest urzeczywistnianie i rozwijanie zasobów. Same relacje są równocześnie jednym z podstawowych zasobów społecznych [...]”. Pobudzenie aktywności lokalnej wymaga wiele wysiłku, jednakże jeden pozytywny przykład jest początkiem lawinowo postępujących po sobie pozytywnych zmian. Oddolny ruch wymaga jednak wsparcia i koordynacji jednostek nadrzędnych w postaci gminy oraz właściwych urzędów (Niedźwiecka-Filipiak 2009; Niedźwiecka-Filipiak, Kuriata 2010). Programy finansowane ze środków polityki strukturalnej sprzyjają tworzeniu dogodnych warunków dla działań prorozwojowych na terenach wiejskich. Jednym z nich jest program LEADER wprowadzony jako metoda pobudzania aktywności lokalnych społeczności oraz ich zaangażowania w poszukiwanie i wykorzystanie drzemiącego na obszarach wiejskich potencjału. Zamierzenia te realizowane są przez Lokalne Grupy Działania (LGD), czyli podmioty (stowarzyszenia), w skład których wchodzą przedstawiciele władz lokalnych, organizacji pozarządowych i przedsiębiorców wprowadzających w życie projekty korzystne z punktu widzenia rozwoju obszarów wiejskich, najczęściej na terenach kilku gmin. Przykładem korzystnego działania programu LEADER są tereny województw lubelskiego i podlaskiego (Kołodziejczak 2011), śląskiego (Kutkowska, Pilawka 2012), wielkopolskiego (Hoffmann, Hoffmann 2018). Program LEADER pozwala społeczności obszarów wiejskich bezpośrednio decydować o celu, na jaki zostaną przeznaczone środki. Realizacja społecznie pożądanych inicjatyw przyczynia się do zrównoważonego rozwoju społeczno-ekonomicznego i aktywizuje ludność miejscową (Zolik 2010; Hadynski, Borucka 2015). Kapitał społeczny jest kategorią zakorzenioną w lokalnej społeczności, nie ma zatem charakteru uniwersalnego i uwarunkowany jest lokalną specyfiką. Uaktywnienie jego kapitału następuje często w sytuacji zagrożenia interesu lokalnej wspólnoty (Gwiaździńska-Goraj i in. 2017). Zaangażowanie mieszkańców może wykazywać wartości ujemne, co stwierdzono w badaniach prowadzonych na terenach wiejskich województwa zachodniopomorskiego (Bedzik, Golab 2018). Pożyteczny przykład aktywizacji rozwoju ekonomiczno-społecznego w układach lokalnych zaobserwowano natomiast w trzech powiatach Lubelszczyzny (Adamowicz 2015).

Warunkiem rozwoju jest wyartykułowanie i chęć dążenia do wspólnego dobra oraz zaistnienie szczególnej okoliczności wyzwalającej potencjał do realnego działania (Marks-Krzyszkowska, Jeziorska-Biel 2017). W budowanie kapitału społecznego duży wkład wnoszą instytucje szczebla regionalnego realizując 
m.in.: szkolenia, doradztwo oraz konferencje i seminaria nt. wykorzystania funduszy UE, rozwoju przedsiębiorczości pozarolniczej, bioróżnorodności, promocji dziedzictwa kulturowego wsi i inne (Mis 2013). Często jednak brakuje mieszkańcom bodźca, który skłoniłby ich do aktywnego uczestnictwa w partycypacji społecznej (Pawlewicz, Kruk 2015). Funkcjonowanie stanowisk ds. komunikacji i animacji w strukturze biur LGD sprzyja zwiększaniu aktywności w realizowanej przez LGD polityce włączenia społecznego (Guzal-Dec, Zwolinska-Ligaj 2017). Do LGD przystępują osoby aktywne społecznie, wzmacniając komponent sieci kapitału społecznego LGD (Zajda 2017). Coraz liczniej powstające instytucje i organizacje działając na rzecz osób starszych, realizują programy promujące zdrowy styl życia wśród tej grupy społecznej, zgodnie z wytycznymi światowych i narodowych programów zdrowia. Ich głównym celem, poza działalnością oświatową i organizacyjną, jest aktywizacja ruchowa seniorów, promująca aktywne formy wypoczynku i rekreacji (Pocztarska-Dec, Bergier 2012).

\subsection{Gmina Konopnica}

Konopnica jest podmiejską gminą położoną na zachodnich peryferiach miasta wojewódzkiego Lublin, a zarazem największego ośrodka miejskiego we wschodniej Polsce. Krajobraz wielkiego miasta zmienia się na obraz osiedli domów jednorodzinnych i przechodzi w typowo wiejskie obszary zabudowy zagrodowej, sadów, pól, łąk i lasów (fot. 1). Gmina jest bardzo dobrze skomunikowana. Przez jej obszar przebiega droga ekspresowa nr S19 (fragment obwodnicy miasta Lublin), droga krajowa nr 19 Lublin-Kraśnik oraz aktualnie modernizowana linia kolejowa Lublin-Warszawa. Gmina położona jest w pobliżu odcinka drogi ekspresowej S17 prowadzącej z Lublina do Warszawy. Rolniczy charakter sołectw ulega coraz bardziej radykalnym przekształceniom, wynikającym głównie z nasilających się procesów suburbanizacji (Studium ... 2010). Obecnie gmina ta jest jedną z najprężniej rozwijających się gmin w województwie lubelskim. Świadczy o tym fakt, że zajęła ona trzecie miejsce w Rankingu Gmin Lubelszczyzny, ogłoszonym przez Fundację Rozwoju Demokracji Lokalnej - Regionalny Ośrodek w Lublinie ${ }^{1}$. Ponadto według danych Departamentu Finansów Samorządu Terytorialnego w Ministerstwie Finansów, wskaźnik (G) podstawowych dochodów podatkowych na jednego mieszkańca gminy Konopnica, przyjęty do obliczania subwencji wyrównawczej na 2018 rok, wynosi 1714,67 zł², co lokuje gminę Konopnica w grupie 20 najbogatszych gmin województwa lubelskiego.

\footnotetext{
${ }^{1}$ http:www.dziennikwschodni.pl (dostęp: 11.01.2019).

${ }^{2}$ http:www.mf.gov.pl (dostęp: 11.01.2019).
} 


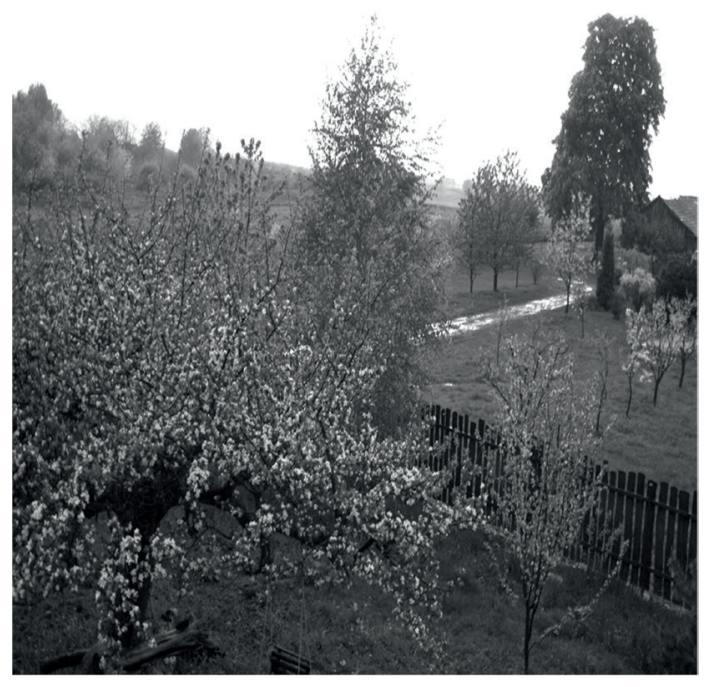

Fot. 1. Krajobraz wsi Motycz w gminie Konopnica fot. J. Szymański (2017)

\subsection{Mocne i słabe strony działań aktywizujących mieszkańców gminy Konopnica w obrazie analizy SWOT}

W ocenie działań aktywizujących mieszkańców gminy Konopnica dokonanych metodą SWOT (Strategia ... 2016) wśród mocnych stron wymieniane są:

- wdrożone standardy współpracy gminy z organizacjami pozarządowymi;

- duża liczba Ochotniczych Straży Pożarnych i ich członków;

- aktywność organizacji pozarządowych z terenu gminy oraz aktywność NGO spoza gminy realizujących swoje projekty na terenie gminy Konopnica;

- udział gminy w Lokalnej Grupie Działania;

- istnienie obiektów i placówek kulturalnych (Dom Kultury w Motyczu, Biblioteka Gminna i jej filie, Ośrodek Działań Twórczych) stymulujących rozwój kulturalny;

- liczne imprezy kulturalne organizowane w gminie, takie jak dożynki, święto wieprzowiny, dni miejscowości gminnych, konkursy nalewek, festyny;

- obecność lotniska w Radawcu Dużym jako miejsca imprez, przede wszystkim dożynek o zasięgu wojewódzkim, powiatowym i pokazów nie tylko z dziedziny lotnictwa;

- obecność prywatnych inicjatyw w dziedzinie turystki i rekreacji (agroturystyka, jazda konna, mała skocznia narciarska);

- obecność obiektów zabytkowych na terenie gminy.

Pośród słabych stron działań aktywizujących występują:

- niewielka liczba organizacji pozarządowych w gminie;

- mała różnorodność działań sektora NGO; 
- niewystarczająca liczba lokali wykorzystywanych na cele aktywizacji społecznej (świetlic, klubów seniora, miejsc spotkań itp.);

- niska aktywność społeczna seniorów;

- zmniejszanie poziomu dofinansowania ze źródeł zewnętrznych dla inwestycji gminnych oraz na utrzymanie istniejących obiektów;

- brak zarejestrowanych produktów regionalnych kojarzonych z gminą;

- niedostateczna promocja inicjatyw kulturalnych z terenu gminy;

- niedostateczna liczba lokali gminnych przeznaczonych na cele kulturalne (ośrodki działań twórczych, domy kultury, świetlice środowiskowe);

- niewystarczająca liczba świetlic wiejskich.

\subsection{Cel i zakres badań}

Celem pracy było zweryfikowanie mocnych i słabych stron aktywizacji społeczeństwa gminy Konopnica wykonanej metodą analizy SWOT. Oceny dokonano przy wykorzystaniu Strategii Rozwoju Gminy na lata 2016-2022 oraz Studium uwarunkowań i kierunków zagospodarowania przestrzennego, jak również materiałów zamieszczonych w informatorze gminnym „Echo Konopnicy”.

\section{Wyniki}

\subsection{Porozumienie gmin LOF}

Porozumienie gmin Lubelskiego Obszaru Funkcjonalnego (LOF) o współpracy w zakresie realizacji Zintegrowanych Inwestycji Terytorialnych (ZIT) w perspektywie finansowej UE 2014-2020, zostało zawarte w dniu 30 marca 2015 roku na mocy art. 74 Ustawy z dnia 8 marca 1990 roku o samorzadzie gminnym ${ }^{3}$. W 2017 roku Lider Projektu podpisał umowę o dofinansowanie projektu pn. „Poprawa spójności przestrzennej, społecznej i kulturowej Lubelskiego Obszaru Funkcjonalnego poprzez rewitalizację", którego celem było przyspieszenie zrównoważonego rozwoju. W ramach projektu gmina Konopnica prowadzi kompleksowe działania $\mathrm{w}$ zakresie przestrzeni, zagospodarowania terenu i adaptacji zdegradowanych obiektów w celu nadania im nowych funkcji. W wyniku materializacji projektu, na terenie gminy Konopnica, w miejscowości Marynin rozbudowywany jest budynek świetlicy wiejskiej i budynki towarzyszące, które będą stanowić jedną bryłę przestrzenną łączącą funkcje Ochotniczej Straży Pożarnej, świetlicy wiejskiej, klubu seniora oraz części mieszkalnej (mieszkania socjalne). Realizacja zadania umożliwi prowadzenie zajęć mających na celu nabywanie nowych umiejętności, wyrównanie szans edukacyjnych osób pochodzących z terenów wiejskich, organizację zajęć o tematyce skierowanej do osób starszych

\footnotetext{
${ }^{3}$ Dz.U., 2013, poz. 594, z późn. zm.
} 
i samotnych. Aktualnie rozbudowywany jest budynek Zakładu Opieki Zdrowotnej Motycz z zamierzeniem stworzenia ośrodka dziennego pobytu dla osób starszych i niepełnosprawnych oraz ośrodka rehabilitacji. W ramach tego samego projektu, w Radawcu Dużym aktualnie prowadzona jest rozbudowa zdewastowanego budynku po byłej Spółdzielni Usług Rolniczych oraz zmiana zagospodarowania terenu wokół budynków. Po zakończeniu inwestycji umieszczona zostanie tam Filia Biblioteki Gminnej oraz wydzielone dwa mieszkania socjalne. Zachętą do aktywności mieszkańców stała się realizacja projektu pn. „Zagospodarowanie placu ćwiczeń OSP Radawiec Duży - boisko, piłkochwyty, ciągi piesze, plac manewrowy, tereny zielone, plac zabaw, altany, ogrodzenie". W miejscowości Konopnica natomiast rozpoczęte zostały prace związane $\mathrm{z}$ budową targowiska wraz z parkingiem i infrastrukturą. W tym miejscu planowana jest promocja lokalnych produktów oraz przedsiębiorczości (Strategia... 2016).

\subsection{Wspólpraca z organizacjami pozarządowymi}

Istotnym elementem prawidłowego funkcjonowania sfery społecznej $\mathrm{w}$ gminie Konopnica jest 15 organizacji pozarządowych: Lokalna Grupa Działania na Rzecz Rozwoju Gmin Powiatu Lubelskiego „Kraina Wokół Lublina”, 12 jednostek Ochotniczej Straży Pożarnej, Pracownia Twórczych Działań, Stowarzyszenie SKAUT. Do stowarzyszenia Lokalna Grupa Działania „Kraina wokół Lublina” należy 50 członków reprezentujących sektory: publiczny, społeczny, gospodarczy. Udział LGD w programie LEADER i realizacja Lokalnej Strategii Rozwoju (LSR) pozwoliły na pozyskanie środków z Programu Rozwoju Obszarów Wiejskich, m.in. dla gminy Konopnica. Zadaniem LGD w perspektywie na lata 2009-2015 był wybór projektów do realizacji w ramach środków przyznanych na wdrożenie strategii. Ze środków przeznaczonych na realizację celów LSR w ramach programu LEADER dofinansowywane były następujące przedsięwzięcia:

- wsparcie dla firm (tworzenie nowych i modernizacja istniejących przedsiębiorstw, chcących wprowadzić nowe technologie i poszerzać swoje rynki zbytu, wspólne działanie promocyjne);

- oferty spędzania wolnego czasu (budowa i modernizacja placów zabaw, organizacja imprez kulturalno-edukacyjnych dla dzieci);

- rozbudowa bazy sportowej i promocja imprez sportowych (budowa i modernizacja obiektów sportowo-rekreacyjnych, organizacja imprez sportowo-rekreacyjnych, szkoleń i warsztatów, zakup strojów, sprzętu dla klubów oraz zespołów sportowych itp.);

- rozwój kultury (budowa i modernizacja obiektów kulturalnych, organizacja imprez rekreacyjno-kulturalnych, szkoleń i warsztatów, tworzenie muzeów, izb regionalnych itp., zakup strojów i instrumentów dla zespołów artystycznych, wydawanie publikacji o charakterze kulturalnym, związanych z lokalną historią, kultywowaniem tradycji itp.); 
- tworzenie szlaków turystycznych „Kraina Wokół Lublina” (tworzenie nowych i modernizacja istniejących gospodarstw agroturystycznych, zagospodarowanie i odnowa centrów wsi i miejsc znajdujących się na szlakach turystycznych, wytyczanie oraz oznakowanie tras turystycznych itp.).

W ramach działania jednostek Ochotniczej Straży Pożarnej wieloletnią tradycją jest opłatek strażacki i konkurs pt. „Karp Po Strażacku” (Wójtowicz 2016b; Wójtowicz 2017).

Do prężnie działających organizacji zaliczane jest „Stowarzyszenie Pracownia Twórczych Działań”, aktywne na terenie Ośrodka Działań Twórczych Gminy Konopnica w Radawczyku Drugim. Powadzi ono cieszące się powodzeniem szkolenia i wykłady na temat chorób i ich profilaktyki (Skowronek-Skałecka i in. 2015).

Stowarzyszenie SKAUT z siedzibą w Lublinie realizuje projekt „Pobudzanie aktywności obywatelskiej poprzez nabywanie nowych umiejętności podczas warsztatów kulturalno-społecznych na rzecz środowiska i społeczeństwa gminy Konopnica". Organizuje również kolonie, zimowiska dla dzieci, często w partnerstwie z Urzędem Gminy. Przy udziale Stowarzyszenia SKAUT, projekt PAS (Program Aktywności Samorządowej) pozwolił na przeprowadzenie zajęć rękodzieła artystycznego przy zastosowaniu techniki decoupage, wyrobów $\mathrm{z}$ ceramiki, malarstwa artystycznego, przedstawień przygotowanych w konwencji teatru cieni. Projekty te od kilku lat są reaktywowane w semestrze jesiennym i wiosennym. W ramach wymienionego projektu wdrożono nowy system monitorowania oraz angażowano mieszkańców w proces konsultowania i podejmowania decyzji w sprawach dotyczących lokalnej społeczności. Wdrożenie modelu zarządzania PAS sprawiło, że pracownicy administracji zyskali wiedzę jak skutecznie reagować na głos obywatelski. Dzięki temu przy współpracy z organizacjami pozarządowymi prowadzono zajęcia dla seniorów pn. „Promocja zdrowia wśród seniorów", gimnastykę i nordic walking. W trakcie 15 spotkań 40 godzinnych, zaaranżowano dla 40 osób pobyt w jaskiniach solnych oraz trening relaksacyjny (Strategia... 2016).

Wśród innych organizacji pozarządowych działających na terenie gminy wymienić należy: Klub Sportowy „Sokół Konopnica”, Fundację „Szkoła Przyszłości”, Towarzystwo „Nowa Kuźnia”, UKS „Widok”, Klub „OYAMA Karate Lublin” oraz „KS Uniszowice” (Strategia... 2016).

W celu wypracowania modelu współpracy jednostek samorządowych z działającymi na ich terenie organizacjami pozarządowymi stworzono projekt „Wdrożenie standardów współpracy administracji publicznej z organizacjami pozarządowymi”. W ramach wdrażania projektu, w gminie Konopnica włączono standardy zarządzania w oparciu o podręcznik K. Więckiewicza i A. Wardęgi (2012)-Model wspótpracy administracji publicznej i organizacji pozarzadowych. Z opisanego w nim modelu współpracy administracji publicznej i organizacji pozarządowych wybrano 6 następujących obszarów: 
- W płaszczyźnie I - Współpraca samorządu terytorialnego i organizacji pozarządowych przy diagnozowaniu lokalnych problemów i wyzwań:

- Obszar 2 - Wzajemne informowanie się samorządu terytorialnego i organizacji pozarządowych o planach, zamierzeniach i kierunkach działań;

- Obszar 4 - Konsultowanie założeń projektów i aktów normatywnych oraz zasad realizacji innych przedsięwzięć;

- W płaszczyźnie II - Współpraca samorządu z organizacjami pozarządowymi w zakresie realizacji zadań publicznych:

- Obszar 1 - Realizacja zadań publicznych z wykorzystaniem form finansowych;

- Obszar 3 - Partnerstwo projektowe w realizacji zadań publicznych;

- W płaszczyźnie III - Infrastruktura współpracy, tworzenie warunków do społecznej aktywności:

- Obszar 1 - System wspierania inicjatyw obywatelskich i organizacji pozarządowych;

- Obszar 3 - Partnerstwo lokalne.

Każdemu z obszarów przypisano szereg wskaźników pomiaru (minimalnych oraz zalecanych) oraz wzorców realizacji. Stworzono dodatkowe wskaźniki opisujące jakość współpracy pomiędzy stronami. Wdrażanie odbywało się w oparciu o zasady ogólne wynikające z Ustawy o działalności pożytku publicznego i o wolontariacie ${ }^{4}$, takie jak: efektywność, pomocniczość, jawność, suwerenność stron, uczciwa konkurencja, partnerstwo, równość szans. Wdrażanie standardów odbywało się w toku spotkań trzyosobowego zespołu roboczego ds. wdrażania. Konsultacje te rozpoczęły się w maju 2014 roku, a zakończyły w marcu 2015 roku. Efektem prac stało się 6 procedur opisujących i regulujących współpracę JST (Jednostek Samorządu Terytorialnego) i NGO w wymienionych obszarach, Roczny Program Współpracy Gminy z Organizacjami Pozarządowymi na 2015 rok oraz Wieloletni Program Współpracy Gminy z Organizacjami Pozarządowymi na lata 2015-2018 (Strategia... 2016).

Wynikiem współpracy gminy Konopnica z organizacjami pozarządowymi jest wysoka aktywność mieszkańców w dziedzinach: kultury, sportu i rekreacji. $\mathrm{Na}$ terenie gminy Konopnica działają grupy i zespoły artystyczne umożliwiające mieszkańcom gminy realizowanie swoich pasji. Jednym z nich jest „Zespół Śpiewaczy Rola” działający w obrębie „Domu Kultury Motycz”. Członkinie zespołu zapraszane są do Akademickiego Centrum Kultury „Chatka Żaka” w Lublinie na spotkania promocyjne kolejnych numerów „Pisma Folkowego” oraz do Muzeum Wsi Lubelskiej w Lublinie w celu uświetniania organizowanych tam imprez, takich jak „Dzień Wiatraka”, „Noc Muzeów”, „Sianokosy”, „Jarmark Koński”, „Noc Świętojańska”, „Niedziela z Lnem” (Kusto 2016; Sulisz 2017c).

\footnotetext{
${ }^{4}$ Dz.U., 2017, poz. 573.
} 
WdziałającymDomuKulturyw Motyczupowstałagrupa teatralna,,Stacja Teatr”, której członkowie uczą się świadomości gry, technik cielesnych, głosowych od aktorów zawodowych teatru im. Juliusza Osterwy w Lublinie. Adepci amatorskiej sztuki teatralnej występują nie tylko na deskach amfiteatru w Motyczu, ale również uczestniczą w znanym w Polsce Europejskim Festiwalu Smaku organizowanym w Lublinie (Sulisz 2016d).

Muzykujący pasjonaci z Kapeli Maki w latach 2016-2017 występowali na dużej scenie w Łęcznej na XX Jubileuszowym Festiwalu Kapel Ulicznych i Podwórkowych, XXIV Muzykowaniu Na Ludową Nutę, Lubartowskim Przeglądzie Kultury Żydowskiej, II Lubartowskim Przeglądzie Kultury, Smaków i Rękodzieła Ziemi Lubelskiej, na Święcie Jagody w Szydłowcu, na IV Międzynarodowym Festiwalu „Łączy nas kultura” w Łopienniku Nadrzecznym, na Europejskim Festiwalu Smaku w Lublinie oraz na stoisku promocyjnym gminy Konopnica w wiosce Lokalnej Grupy Działania „Kraina wokół Lublina” (Zawadzka 2017).

Grupa baletowa Arabeski w 2016 roku zakończyła roczny projekt współfinansowany przez Urząd Gminy Konopnica. Uczestniczki wzięły udział w warsztatach z mistrzami baletu - absolwentami Państwowej Szkoły Baletowej w Gruzji ${ }^{5}$.

Na terenie Motycza działa grupa „Malarki z Konopnicy”, która w 2017 roku przygotowała wystawę prac pt. „Motycz w obrazach” (fot. 2), zaprezentowaną podczas uroczystości 700-lecia Motycza (Sulisz 2017g).

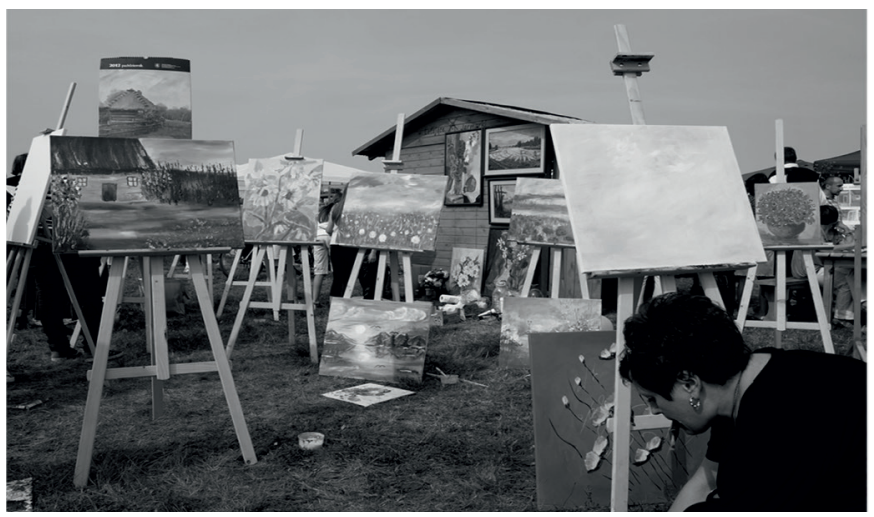

Fot. 2. Plener grupy „Malarki z Konopnicy” fot. J. Szymański (2017)

Dom Kultury w Motyczu regularnie zaprasza mieszkanki gminy do udziału w warsztatach pn. „Przekaż tradycję” organizowanych w celu m.in. kultywowania tradycji tworzenia palm wielkanocnych i wieńców dożynkowych (Sulisz 2016e). Prowadzone są pokazy kulinarne pt. „Pierogi Motyckie” oraz „Turniej Nalewek” (Sulisz 2017j). Wyjątkowo uroczyście obchodzone są Złote Gody 50-letnich par małżeńskich, w trakcie których jubilatom wręczane są medale nadawane przez Prezydenta RP (Wójtowicz 2016a). Dwa razy w miesiącu przy muzyce na żywo

\footnotetext{
${ }^{5}$ http:www.facebook.com/arabeski.konopnica (dostęp: 11.01.2017).
} 
integrują się seniorzy oraz biorą udział w organizowanych co kwartał wycieczkach krajoznawczych (Sulisz 2016a, 2016b).

W ramach działań współfinansowanych ze środków Rządowego Programu na Rzecz Aktywności Społecznej Osób Starszych na lata 2014-2020, realizowanych przez Stowarzyszenie HELIO „Kultura oczami 2 pokolen” oraz przez Fundację Rozwoju Inicjatyw Obywatelskich „Aktywny Senior w aktywnej Gminie” zrealizowane zostały warsztaty aktywności społecznej oraz E-mobilny senior, warsztaty z rękodzieła - malowanie na szkle, w ramach własnych inicjatyw - zdrowe gotowanie, warsztaty teatralne/wokalne oraz wizyta studyjna - zwiedzanie Roztocza. Kilkunastu seniorów, wspólnie z seniorami z gminy Niemce i Niedrzwica Duża, uczestniczyło w wycieczce - Karpacz, Jelenia Góra, Drezno. Seniorzy mają możliwość korzystania z propozycji Pracowni Działań Twórczych w Radawczyku Drugim w ramach projektu „Zdrowy junior, zdrowy senior” dotowanych przez gminę Konopnica. Wśród ofert znalazły się dotychczas: wycieczka do Kopalni Soli w Wieliczce, piknik pokoleniowy, seans w jaskini solnej, trening pamięci oraz warsztaty eco (Wróblewska 2018). Wśród cyklicznych imprez integrujących mieszkańców należy wymienić „Motycki Hubertus”, w czasie którego dzieci mają możliwość zaprezentowania swoich osiągnięć przed lokalną publicznością (Radzik, Hetman 2016; Wilczek 2017). Dużą aktywność wykazują kobiety zrzeszone w 12 Kołach Gospodyń Wiejskich (Niedziałek 2016).

Mieszkańcy gminy w 2017 roku wzięli udział w akcji pn. „Dawny portret ślubny mieszkańców gminy Konopnica”, dzięki której stworzono wystawę fotograficzną w plenerze (Staszak 2017). W tym samym roku zrealizowano projekty: „Konopnickie pasje” (Wróblewska 2016), „Zdrowy junior, zdrowy senior” oraz wspólfinansowany przez Starostwo Powiatowe w Lublinie projekt „Twórcze pasje” (Sulisz 2017h). Na terenie Aeroklubu Lubelskiego w Radawcu co roku odbywa się Święto Plonów (fot. 3), w czasie którego oceniane są wieńce dożynkowe (Sulisz 2017e).

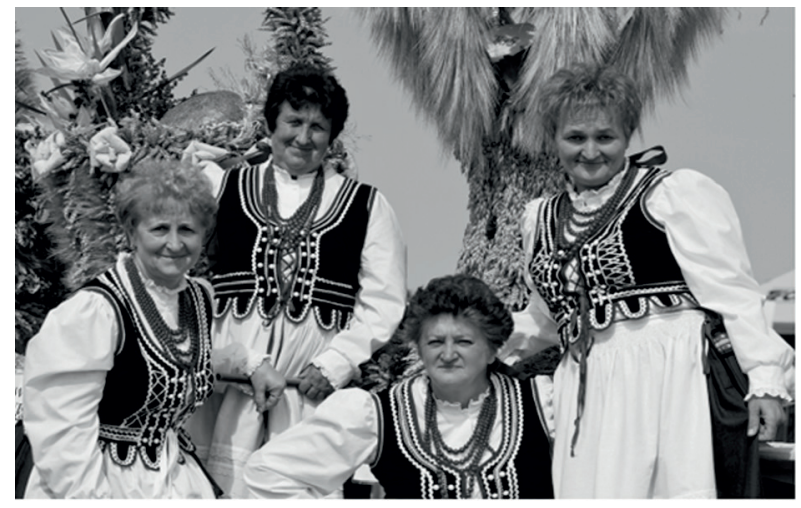

Fot. 3. Panie z Koła Gospodyń Wiejskich w Sporniaku w czasie Święta Plonów fot. J. Szymański (2017) 


\subsection{Efekty programu LEADER}

Udział LGD w programie LEADER i realizacja Lokalnej Strategii Rozwoju (LSR) pozwoliły na pozyskanie środków z Programu Rozwoju Obszarów Wiejskich dla gminy Konopnica, a także innych, wchodzących w skład stowarzyszenia. Lokalna Strategia Rozwoju LGD była realizowana w latach 2009-2015 i obejmowała działania w czterech obszarach. Jeden z nich dotyczył odnowy i rozwoju wsi, drugi obejmował małe projekty dedykowane gminom i organizacjom pozarządowym (Strategia ... 2016). Ze środków przeznaczonych na realizację celów LSR $\mathrm{w}$ ramach programu LEADER dofinansowywane były przedsięwzięcia $\mathrm{w}$ zakresie: wsparcia dla firm (tworzenie nowych i modernizacja istniejących przedsiębiorstw z różnych branż, chcących wprowadzać nowe technologie i poszerzać swoje rynki zbytu; wspólne działania promocyjne), poprawy oferty spędzania wolnego czasu (budowa i modernizacja placów zabaw, organizacja imprez kulturalno-edukacyjnych dla dzieci), wzmocnienia bazy sportowej i promocji imprez sportowych (budowa i modernizacja obiektów sportowo-rekreacyjnych, organizacja imprez sportowo-rekreacyjnych, szkoleń i warsztatów, zakup strojów, sprzętu dla klubów oraz zespołów sportowych i in.), kultury (budowa i modernizacja obiektów kulturalnych, organizacja imprez rekreacyjno-kulturalnych, szkoleń i warsztatów, tworzenie muzeów, izb regionalnych itp., zakup strojów i instrumentów dla zespołów artystycznych, wydawanie publikacji o charakterze kulturalnym, związanym z lokalną historią, kultywowaniem tradycji itp.), tworzenia szlaków turystycznych „Kraina Wokół Lublina” (tworzenie nowych i modernizacja istniejących gospodarstw agroturystycznych, zagospodarowanie i odnowa centrów wsi i miejsc znajdujących się na szlakach turystycznych, wytyczanie oraz oznakowanie tras turystycznych itp.), promowania lokalnej sztuki kulinarnej (tworzenie nowych przedsiębiorstw branży przetwórstwa rolno-spożywczego, promocja produktów lokalnych i szkolenia w tym zakresie). W gminie powołano zespół ds. dialogu społecznego jako płaszczyzny uzgodnienia stanowisk i wypracowania projektów. W skład zespołu weszło trzech przedstawicieli UG Konopnica oraz sześciu reprezentantów środowisk pozarządowych (NGO). Wypracowane rozwiązania były także przedmiotem spotkań prowadzonych metodą RADAR, w których oprócz członków zespołów, uczestniczyli aktywni mieszkańcy i przedstawiciele sektora NGO. Istotnym elementem prawidłowego funkcjonowania sfery społecznej wsi jest rozwinięta sieć organizacji pozarządowych i różnorodnych form współpracy ze środowiskiem NGO (skrót od ang. non-governmental organizations, czyli organizacje pozarządowe - struktury powstające w wyniku inicjatyw obywatelskich). Rozwój tej sfery życia społecznego możliwy jest dzięki wsparciu finansowemu, możliwemu do pozyskania z coraz większej liczby źródeł. Samorząd wspólnie z organizacjami promuje działania w ramach lokalnych wydarzeń, tj. festyny, imprezy plenerowe. Do najważniejszych należą: uroczystość 
obchodów 100. rocznicy Odzyskania Niepodległości, uroczystość 700-lecia powstania wsi Motycz, coroczne dożynki wojewódzkie na lotnisku w Radawcu Dużym, Hubertus Motycki (Strategia... 2016).

\subsection{Wdrożenie samooceny metodą Lokalnego Indeksu Wspólpracy}

Oprócz wskaźników opisanych w „Modelu współpracy administracji publicznej i organizacji pozarządowych", na potrzeby realizacji projektu powstały dodatkowe dedykowane wskaźniki, mające służyć samoocenie metodą Lokalnego Indeksu Współpracy. W tym celu stworzono grupę ds. samooceny, w skład której weszli przedstawiciele Urzędu Gminy oraz reprezentanci NGO. Dokonana ocena miała dualistyczny charakter. W oparciu o wskaźniki wykonano ankiety dla urzędników oraz przedstawicieli NGO. Po przeprowadzeniu analizy ankiet, opracowano rekomendacje dotyczące poprawy oraz usprawnień w zakresie współpracy UG i NGO. Program współpracy z NGO posiada bardzo szeroki zakres. Z roku na rok środki zabezpieczone na ten cel rosną. W 2015 roku zaplanowano w budżecie gminy ponad 150 tys. zł na realizację zadań publicznych, natomiast od 2018 roku budżet ten wynosi już 300 tys. zł (Skowronek-Skałecka i in. 2015).

Od 2016 roku w ramach dwóch spotkań z mieszkańcami gminy w ciągu roku tworzony jest katalog inicjatyw dookreślonych statusem stopnia realizacji. Katalog ten zawiera niespełna 40 postulatów. 24 z nich nadano status „ma miejsce, w trakcie lub planuje się”, stan pozostałych postulatów określono mianem „niemożliwe z prawnego punktu widzenia, nie planuje się, częściowo ma miejsce, niemożliwe do czasu wygaśnięcia umowy z dzierżawcą, niemożliwe - brak warunków lokalowych". Do postulatów objętych w różnym stopniu realizacją należą: udostępnienie sal gimnastycznych, boisk sportowych, placów zabaw społeczeństwu; supremacja edukacji kulturalnej w Ośrodku Działań Twórczych w Radawczyku Drugim oraz Domu Kultury w Motyczu poprzez rozkwit ognisk muzycznych, plastycznych, teatralnych; wyłonienie i popularyzowanie produktów lokalnych, takich jak nalewki, wędliny, chleb, zdrowa żywność, sery, miody (Strategia... 2016).

\subsection{Oddolne inicjatywy mieszkańców}

Dzięki systematycznie zwiększającym się dochodom gminy Konopnica, coraz większa ilość środków przekazywana jest organizacjom pozarządowym, wykonującym zadania kulturalne zorientowane na mieszkańców gminy w ramach ogłaszanych przez gminę konkursów. Efektem przekazywanych funduszy i pracy organizacji pozarządowych jest realizacja zajęć proponowanych przez samych mieszkańców gminy (Sulisz 2018). Każdego roku w czasie Parafialno-Gminnego Dnia Seniora w Konopnicy, starsi mieszkańcy z miejscowości Konopnica, Stasin, 
Marynin, Zemborzyce Tereszyńskie, Uniszowice, Kozubszczyzna, Tereszyn mają okazję spotykać się z poezją, śpiewem i tańcem, a także aranżacją instrumentalną. Program artystyczny wykonywany jest przez uczniów gminnych szkół, artystki Zespołu Śpiewaczego „Rola” z Motycza, aktorów „Stacji Teatr w Konopnicy” (Sulisz 2016a, 2016b, Sulisz 2017b).

W Radawcu na lotnisku Aeroklubu Lubelskiego odbywają się Spotkania Modelarzy, w trakcie których można podziwiać latające modele samolotów i szybowców (Sulisz 2016c). Dla miłośników szybkości organizowane są wyścigi dronów oraz pokazy balonów (Sulisz 2017d, 2017f). Tu również odbywają się Gminne Zawody Sportowo-Pożarnicze Ochotniczych Straży Pożarnych, w których biorą udział drużyny ze wszystkich jednostek OSP gminy Konopnica (Sulisz 2017h).

Rokrocznie w amfiteatrze w Motyczu odbywa się Gala Orkiestr Dętych (fot. 4). W 2017 roku w prezentacji wzięły udział cztery orkiestry, m.in. Młodzieżowo-Dziecięca Orkiestra Dęta z Motycza (Sulisz 2017a).

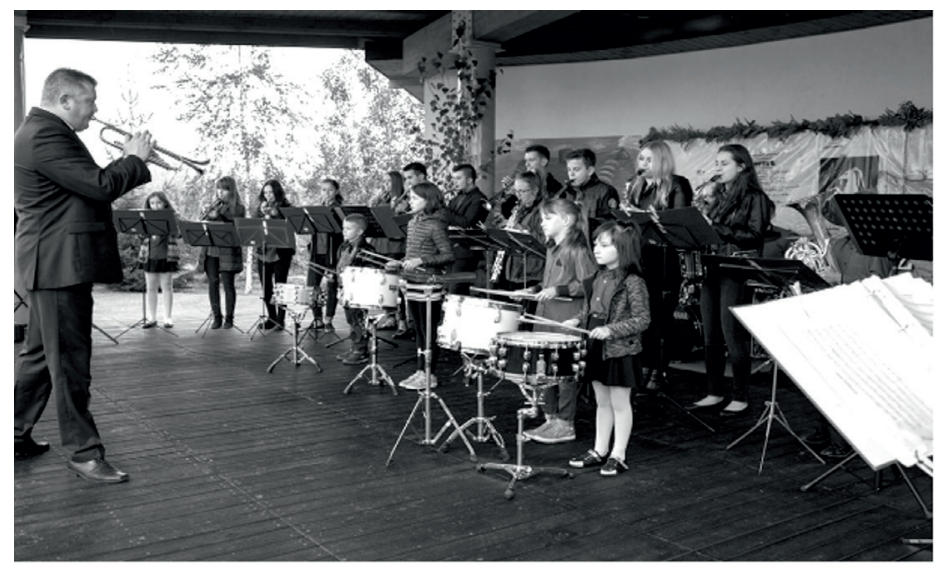

Fot. 4. Występ Młodzieżowo-Dziecięcej Orkiestry Dętej z Motycza w czasie obchodów 700-lecia lokacji

fot. J. Szymański (2017)

W 2017 roku Motycz świętował Jubileusz 700-lecia nadania praw lokacyjnych. Cykl obchodów rozpoczęła w styczniu uroczysta msza święta (fot. 5) podczas, której odczytany został akt lokacji Motycza: ,[...] my Władysław z Bożej łaski książę Krakowa, Sandomierza, Sieradza, Łęczycy i Kujaw, a także dziedzic całego Królestwa Polskiego [...], rozważywszy i poznawszy zasługi i wierne służby okazane nam przez braci rodzonych Dzierżka i Ostasza, dziedziców z Bejsc, [...] przyznajemy i dozwalamy, aby dziedzictwo ich [...] Motycz [...] na wieki był urządzony wedle prawa niemieckiego średzkiego [...]. Dane w Krakowie, w roku Pańskim 1317, w dniu błogosławionego Andrzeja Apostoła" (Podkowińska 2017; Sulisz 2017i). 


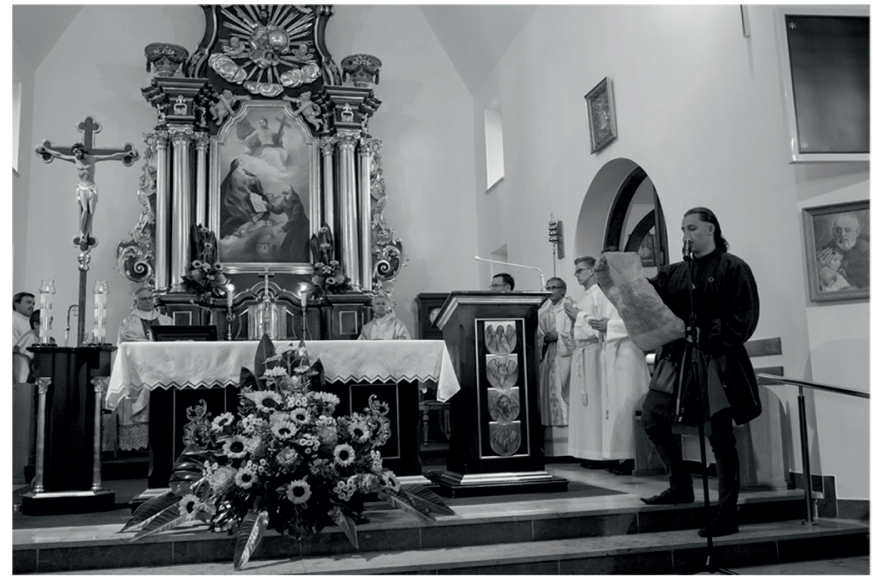

Fot. 5. Odczytanie aktu lokacyjnego Motycza w kościele p.w. Matki Bożej Anielskiej w Motyczu

fot. J. Szymański (2017)

\subsection{Integracja międzynarodowa}

Jednym z najciekawszych pomysłów aktywizacji mieszkańców gminy łączącym przeszłość z teraźniejszością, opartym o środki ze „Wspólnego sekretariatu technicznego" jest Projekt „Promotion of land culture and preservation of historical heritage", dla którego to pomysłu powstała fiszka projektowa dotycząca rozwoju współpracy pomiędzy miejscowością Trembowla, obwód Tarnopol na Ukrainie a Motyczem w gminie Konopnica, powiat lubelski, Polska. Do tej pory współpraca polegała na wymianie dzieci i młodzieży, wzajemnym poznawaniu się, prowadzeniu wspólnych zajęć, wycieczek, planowaniu wspólnych przedsięwzięć. Gmina Konopnica szczyci się posiadaniem ruin grodziska pochodzącego z VIII wieku (n.e.), natomiast Trembowla ruinami historycznego zamku i monastyru. Miejscowości te znalazły się na szlaku handlowym z Rusi Kijowskiej do Rzeczypospolitej. Pomysł ma za zadanie porozumienie się młodych pokoleń obydwu krajów, wzajemne wsparcie i rozwój w przyszłości, z jednoczesnym wyłączeniem wątku historycznych sporów. Nie udało się dotąd pozyskać funduszy na ten cel, jednak gmina podtrzymuje pomysł i jest na etapie dalszego poszukiwania środków. W efekcie realizacji projektu zostanie odrestaurowane grodzisko i podgrodzie (ryc. 1), w obszarze którego powstanie muzeum ze stałą ekspozycją historycznego sprzętu rolniczego. W chwili obecnej polskie eksponaty są wymieniane $\mathrm{z}$ ukraińskimi. Cyklicznie organizowane będą targi środowiskowe $\mathrm{z}$ towarzyszącymi im: inscenizacjami turniejów rycerskich, sprzedażą rękodzieła artystycznego, targami i gonitwami koni. Na terenie gminy Konopnica funkcjonują małe stadniny, które zostaną włączone do projektu przygotowanego specjalnie 
dla osób objętych resocjalizacją, zarówno młodzieży, jak i osób dorosłych, a także osób zagrożonych wykluczeniem społecznym, poprzez zaangażowanie do opieki nad końmi. W obrębie działania grodziska będą organizowane zajęcia hortiterapii (ogrodolecznictwa) jako uzupełnienie tradycyjnych form rehabilitacji dla osób z problemami zdrowotnymi (Skowronek-Skałecka i in. 2015).

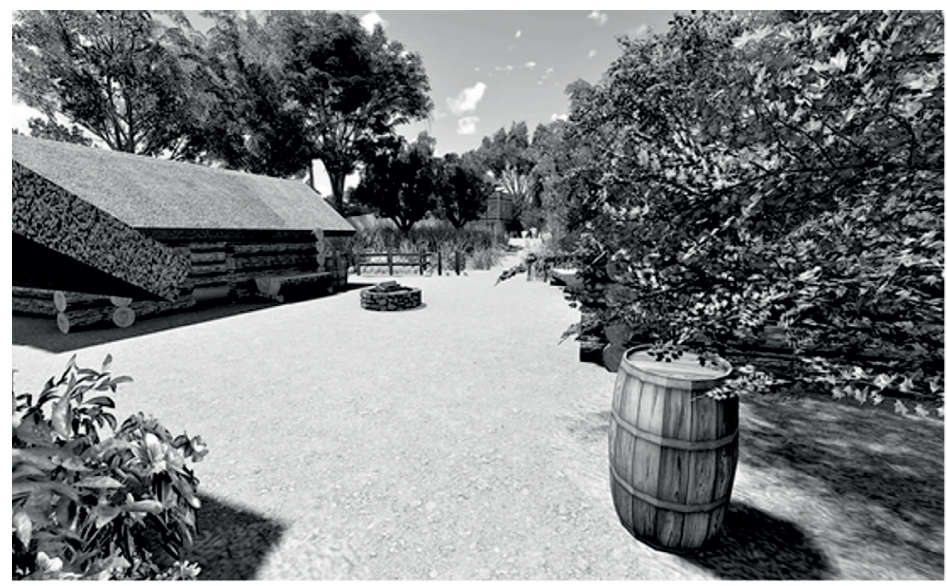

Ryc. 1. Wizualizacja projektu rewitalizacji grodziska w Motyczu Źródło: B. Palak (2015)

\section{Podsumowanie}

$\mathrm{Na}$ terenie gminy Konopnica panuje sprzyjający klimat do aktywizacji i integracji mieszkańców. Dzięki pozyskiwanym funduszom unijnym, Gmina wspiera integrację i aktywizację środowiska wiejskiego. Mieszkańcy rozwijają pasje artystyczne (teatr amatorski „Stacja Teatr”, „Zespół Śpiewaczy Rola”), kulturalne (Dom Kultury w Motyczu, Biblioteka Gminna i jej filie, Ośrodek Działań Twórczych w Radawczyku Drugim), edukacyjne (sala komputerowa w Domu Kultury w Motyczu), sportowe (boisko i siłownia w Motyczu). Gmina kładzie duży nacisk na dbałość o pokolenie emerytów i rencistów (organizacja Złotych Godów, aktualnie dostosowywanie budynku po byłym ZOZ na potrzeby opieki dziennej i rehabilitacji). Z aktywizacji w dużej mierze korzystają autochtoni należący do najmłodszej i najstarszej grupy wiekowej. Mankamentem jest małe zaangażowanie w życie społeczne ludności napływowej oraz reprezentantów średniego pokolenia.

Oceniając zaangażowanie gminy Konopnica w działania aktywizujące mieszkańców należy stwierdzić, że słabe strony wymienione w analizie SWOT stopniowo ulegają niwelacji na korzyść mocnych stron. 


\section{Literatura}

Adamowicz M., 2015, Lokalne strategie innowacji jako narzędzie zarzadzania rozwojem powiatów stanowiacych obszary potencjalnego wzrostu Lubelszczyzny, „Roczniki Naukowe Stowarzyszenia Ekonomistów Rolnictwa i Agrobiznesu", 17(3): 11-18.

Bedzik B., Golab S., 2018, Zaangażowanie lokalnej społeczności w sprawy gminy. Implikacje dla kapitału społecznego, „Folia Pomeranae Universitatis Technologiae Stetinensis. Oeconomica", 90: 17-28.

Brodziński Z., 2011, Stymulowanie rozwoju obszarów wiejskich na poziomie lokalnym na przykładzie gmin województwa warmińsko-mazurskiego, Wydawnictwo SGGW, Warszawa: 131-132.

Guzal-Dec D., Zwolinska-Ligaj M., 2017, Lokalne grupy działania na rzecz właczenia społecznego w województwie lubelskim, ,Roczniki Naukowe Stowarzyszenia Ekonomistów Rolnictwa i Agrobiznesu", 19(3): 71-78.

Gwiaździńska-Goraj M., Goraj S., Sobolewska-Węgrzyn B., 2017, Rola kapitału społecznego w rozwoju obszarów wiejskich na przykładzie wsi Ruś, „Studia Obszarów Wiejskich", 46: 27-39.

Hadynski J., Borucka K., 2015, Aktywizacja obszarów wiejskich Unii Europejskiej w kontekście programu LEADER w Wielkopolsce, ,Journal of Agribusiness and Rural Development", 1(35): 49-56.

Heffner K., Klemens B., 2012, Warunki życia i aktywność społeczno-gospodarcza mieszkańców na obszarach wiejskich (na przykładzie województwa opolskiego), „Barometr Regionalny", 4(30), Wydawnictwo Politechniki Opolskiej, Opole: 86-87.

Hoffmann R., Hoffmann N., 2018, The LEADER Programme as an Impulse for New Projects in Rural Areas, „Quaestiones Geographicae”, 37(2): 141-150.

Kołodziejczak A., 2011, Lokalne Grupy Działania jako czynnik rozwoju wiejskich obszarów peryferyjnych $w$ województwach lubelskim i podlaskim, [w:] Wesołowska M. (red.), Wiejskie obszary peryferyjne - uwarunkowania i czynniki aktywizacji, ,Studia Obszarów Wiejskich", 26, Warszawa: 203-214.

Kusto A., 2016, Wyśpiewać Sobie i Wszystkim Świętym, „Echo Konopnicy”, 12: 7.

Kutkowska B., Pilawka T., 2012, Program odnowy wsi jako instrument wzmacniajacy jakość kapitału społecznego, ,Roczniki Naukowe Stowarzyszenia Ekonomistów Rolnictwa i Agrobiznesu", 14(3): 232-237.

Marks-Krzyszkowska M., Jeziorska-Biel P., 2017, Potencjał społeczności lokalnych w rozwoju turystyki Żuławek, „Studia Obszarów Wiejskich”, 46: 7-25.

Mis T., 2013, Budowanie kapitału społecznego na obszarach wiejskich w Polsce przez instytucje szczebla regionalnego, „Roczniki Naukowe Stowarzyszenia Ekonomistów Rolnictwa i Agrobiznesu", 15(1): 153-158.

Niedziałek A., 2016, Tak było na Święcie Plonów, „Echo Konopnicy”, 7-8: 8.

Niedźwiecka-Filipiak I., 2009, Wyróżniki krajobrazu i architektury wsi Polski południowo-zachodniej, Wydawnictwo Uniwersytetu Przyrodniczego we Wrocławiu, Wrocław.

Niedźwiecka-Filipiak I., Kuriata Z., 2010, Architektura krajobrazu w programie odnowy wsi opolskiej, Wydawnictwo Uniwersytetu Przyrodniczego we Wrocławiu, Wrocław. 
Palak B., 2015, Projekt zagospodarowania terenu przy wczesnośredniowiecznym grodzisku w Motyczu, Praca inżynierska wykonana na Wydziale Matematyki, Informatyki i Architektury Krajobrazu KUL.

Pawlewicz K., Kruk M., 2015, Partycypacja i komunikacja społeczna $w$ planowaniu rozwoju lokalnego na przykładzie gminy wiejskiej Zaręby Kościelne, ,Roczniki Naukowe Stowarzyszenia Ekonomistów Rolnictwa i Agrobiznesu", 15(4): 231-236.

Pocztarska-Dec A., Bergier J., 2012, Aktywność ruchowa ludzi starszych w świetle dotychczasowych badań, „Człowiek i Zdrowie”, 06(1): 23-38.

Podkowińska M., 2017, Uroczystości Jubileuszowe w Motyczu, „Echo Konopnicy”, 7-9: $7-10$.

Radzik K., Hetman K., 2016, IV Hubertus w Motyczu, „Echo Konopnicy”, 9-11: 12.

Rosiński D., Rosińska A., 2011, Społeczności i organizacje jako środowisko wzmacniania kompetencji społecznych: problemy badawcze i potrzeby praktyki, Polityka społeczna, Warszawa: 5-10.

Skowronek-Skałecka A., Kędziora K., Grabarska A., Żydek M., Pietrzak Ł., Żydek K., 2015, Realizacja projektu ,Wdrożenie standardów wspótpracy administracji publicznej z organizacjami pozarzadowymi” przez Urzad Gminy Konopnica w okresie maj 2014 r.-marzec 2015 r.

Staszak M., 2017, Historia Motycza na starej fotografii, „Echo Konopnicy”, 7-9: 7.

Strategia Rozwoju Gminy na lata 2016-2022 (Uchwała Nr XXV/159/2016 Rady Gminy Konopnica z dnia 30 sierpnia 2016 roku w sprawie przyjęcia Strategii Rozwoju Gminy Konopnica na lata 2016-2022), http:www.konopnica.eu (dostęp: 1.01.2018).

Studium uwarunkowań i kierunków zagospodarowania przestrzennego Gminy Konopnica (Uchwała Nr XLVI/252/10 Rady Gminy Konopnica z dnia 21 czerwca 2010 roku). Sulisz M., 2016a, Dzień Seniora w Motyczu, „Echo Konopnicy”, 1-2: 10-11.

Sulisz M., 2016b, Dzień Seniora w Konopnicy, „Echo Konopnicy”, 4-6: 10.

Sulisz M., 2016c, Sekcja Modelarska z Radawca w Lublinie, „Echo Konopnicy”, 9-11: 7. Sulisz W., 2016d, Tu Stacja Teatr, „Echo Konopnicy”, 1-2: 14-15.

Sulisz W., 2016e, Przekaż Tradycję, „Echo Konopnicy”, 4-6: 2, 5.

Sulisz M., 2017a, Gala Orkiestr Dętych, „Echo Konopnicy”, 5-6: 11.

Sulisz M., 2017b, Dzień Seniora w Motyczu, „Echo Konopnicy”, 1-2: 10-11.

Sulisz M., 2017c, Kolęda 700 Wspólnych Lat, „Echo Konopnicy”, 1-2: 14.

Sulisz M., 2017d, VI Spotkanie Modelarzy - Piknik w Radawcu, „Echo Konopnicy”, 5-6: 17.

Sulisz M., 2017e, Dożynki Wojewódzkie, „Echo Konopnicy”, 7-9: 4, 5.

Sulisz M., 2017f, 90-lecie Aeroklubu Lubelskiego, „Echo Konopnicy”, 7-9: 12.

Sulisz M., 2017g, Malarki z Konopnicy w Lublinie, „Echo Konopnicy”, 7-9: 17.

Sulisz M., 2017h, Konopnickie Pasje, „Echo Konopnicy”, 10-12: 20.

Sulisz W., 2017i, To Będzie Bardzo Dynamiczny Rok, „Echo Konopnicy”, 1-2: 2, 3.

Sulisz W., 2017j, Wybrali Królowa Nalewek Gminy Konopnica, „Echo Konopnicy”, 10-12: 18 .

Sulisz W., 2018, Do czterech razy sztuka, „Echo Konopnicy”, 10-12: 6.

Więckiewicz K., Wardęga A., 2012, Model wspótpracy administracji publicznej i organizacji pozarzadowych, Instytut Spraw Publicznych, Warszawa. 
Wilczek B., 2017, Hubertus Motycki, „Echo Konopnicy”, 10-12: 17.

Wójtowicz J., 2016a, Złote Gody w Gminie Konopnica, „Echo Konopnicy”, 9-11: 8, 11. Wójtowicz J., 2016b, Karp Po Strażacku, „Echo Konopnicy”, 1-2: 6.

Wójtowicz J., 2017, Karp Po Strażacku, „Echo Konopnicy”, 1-2: 6.

Wróblewska A., 2018, Seniorze! Teraz masz czas dla siebie!, „Echo Konopnicy”, 7-9: 13. Zajda K., 2017, Bricolage w wykorzystaniu zasobów spolecznych wsi. Relacja między zasobami społecznymi obszarów partnerstw a kapitałem społecznym lokalnych grup działania z województw o odmiennych tradycjach społecznikowskich, „Studia Obszarów Wiejskich", 46: 117-129.

Zawadzka G., 2017, Co stychać u Naszej Kapeli Konopnickiej, „Echo Konopnicy”, 10-12: 21.

Zolik M., 2010, Wdrażanie inicjatywy LEADER+ w krajach UE-10 w latach 2004-2006, „Journal of Agrobusiness and Rural Development”, 01(15): 131-144.

Akty prawne

Ustawa z dnia 8 marca 1990 roku o samorzadzie gminnym (Dz.U., 2013, poz. 594, z późn. zm.).

Ustawa z dnia 10 lutego 2017 roku o działalności pożytku publicznego i o wolontariacie (Dz.U., 2017, poz. 573).

\title{
Źródła internetowe
}

http:facebook.com/arabeski.konopnica.

http:www.dziennikwschodni.pl.

http:www.mf.gov.pl, Ministerstwo Finansów.

\section{ACTIVATION AND INTEGRATION OF RESIDENTS OF THE KONOPNICA COMMUNE WITH REFERENCE TO STRENGHT AND WEAKNESS ANALYSIS (SWOT ANALYSIS)}

\begin{abstract}
The Konopnica Commune, adjacent to the voivodeship capital Lublin, is of agricultural character. Due to transformations in the agricultural economy and inflow of population from the nearby city, the social sphere of life is gaining importance. One of the elements of its proper functioning is the developed network of non-governmental organisations and various forms of cooperation with the NGO environment. Many initiatives activating residents are implemented in the commune. The most interesting one is the international project "Promotion of land culture and preservation of historical heritage" conducted together with the Trembowla municipality in the Tarnopol oblast in Ukraine.

The following associations are active in the area of the commune: Association Local Action Group for the Development of the Lublin Poviat "Kraina wokó Lublina", 12 units of the Volunteer Fire Brigade, Association "Pracownia Twórczych Działań", and Association "Skaut" with its seat in Lublin, implementing cultural-social workshops in the Konopnica Commune.
\end{abstract}


Residents of the commune implement and develop passions in groups and artistic teams, including: singing group "Rola", theatre group "Stacja Teatr", ballet group "Arabeski", group "Malarki z Konopnicy", and a music band. Owing to the work of enthusiasts, cultural-social meetings are organised in the form of cyclical events and one-off actions.

The cultural development is stimulated by cultural entities ("Dom Kultury" in Motycz, Commune Library and its branches, Ośrodek Działań Twórczych).

The aforementioned advantages of the Konopnica Commune offer a chance for its development both in the socio-economic sphere and in terms of cultural-environmental heritage.

Keywords: Konopnica, Lublin, voivodeship, social activation, social integration.

Dr inż. Beata Żuraw

Katedra Roślin Przemysłowych i Leczniczych

Wydział Agrobioinżynierii

Uniwersytet Przyrodniczy w Lublinie e-mail: beata.zuraw@up.lublin.pl

Mgr inż. Małgorzata Szymańska

Kancelaria Nieruchomości

Motycz k. Lublina

e-mail: malgorzata@szymanska-wycena.pl

Mgr Mirosław Żydek

Urząd Gminy Konopnica

e-mail: sekretariat@konopnica.eu 